\title{
Media Representation of Women Politicians from a Gender to an Intersectionality Perspective
}

\section{By Christina FIIG}

Over the past thirty years, ethnic majority women politicians have gained a high representation in Danish politics. The article focuses on how the media form a specific political site for women politicians regarding representation and selfrepresentation from an intersectional perspective. It looks critically at previous research about the media representation of women politicians in written press coverage, which mainly applies a gender perspective. The case-study of the media representation of an ethnic minority woman politician raises new questions about the media as a site of discrimination and/or empowerment of these politicians.

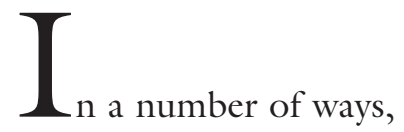

the Nordic countries appear to be swi generis when it comes to ethnic majority women's political participation and representation in politics. ${ }^{1}$ Since the 1970 s, the countries have been described as 'a laboratory of gender equality' (Gomard and Krogstad 2001) concerning descriptive political representation. ${ }^{2}$ But the status as role model has been challenged in different ways (Fiig 2009a, 2009b). Concerning Denmark, one such challenge comes from media representation of women politicians of majority and minority origin. Women politicians frequently point to perceived biases in their treatment by the press as a clear-cut example of gender inequality in politics (Carroll and Schreiber 1997, Moustgaard 2004a). Studies document how the media employ a particular vocabulary, which tends to stereotype and label women politicians and other categories of women (Andreassen 2005, 2006, Eide 2000, Gomard and Krogstad 2001, Hage- 
mann and Krogstad 1994, Moustgaard 2004a, 2004b).

Within a framework of media and power, I investigate 1) how media representation of women politicians is presented in international and Nordic research and 2) how a politician with a minority background is represented in the Danish written press in terms of categories of social differences such as age, ethnicity, and gender. I do so by analysing newspaper articles constructing the election campaign and the election of the politician Özlem Cekic to the Danish Parliament in 2007. This works as an explorative study of media representation of a specific politician in the Danish media. The analytical point of the article is that a perspective of intersectionality deepens the understanding of the ways the media organize power through stereotypical representation and homogenization of social categories. The point being that both phenomena can be sexist and racist. ${ }^{3}$

The article first presents the concept of media representation and a perspective of intersectionality before proceeding to a section on research on media representation of women politicians. In the final sections, I present the empirical case on media representation pointing at the specific ways these representations are constructed as an intersection of class, ethnicity, gender, and religious beliefs in the case of an ethnic minority politician.

\section{MEDIA REPRESENTATION}

Words count in politics. Through frequent repetition, their effect can be to diminish a woman's status as a competent politician. The media equally count in politics. In what follows the media are understood as the written media, i.e. newspaper articles. The media are not a mirror of politics but central agents in its construction. The media create an arena for the negotiation of images and of political competences (Gomard and Krogstad 2001). An empirical example of the media's political power potential is a survey of Danish parliamentarians, in which the MPs ascribe a significant degree of power to the Danish media institutions and approach the media as a political agency participating in the political game. They ascribe almost as much power potential to the media as they do to the national government (Jensen 2004).

I describe the media's representation of women politicians as a double-sided phenomenon: on the one hand, a symbolic representation based on possible gendered and racialized stereotypes (Childs 2008) and, on the other hand, an agency and a means to empowerment as a result of exposure in the media (Ross 2003). The latter aspect implies that women politicians are not simply passive recipients of media representations but can also participate in their construction. The analytical trick is to walk a narrow line between the two understandings of media representation as both discriminatory and empowering/productive.

In 1981, Sapiro linked descriptive and symbolic political representation of women politicians by pointing out that “... greater numbers of women in office would increase the acceptability of women in government and change the cultural impressions of politics" (Sapiro 1998: 183; here from Childs 2008: 141). This anticipated positive link between the increasing number of women in politics and positive media representation has been challenged by research. In the case of Denmark, analysis of the written press coverage of women parliamentarians (Moustgaard 2004a, 2004b), of two Danish national TV-channels' coverage of visible minorities (Andreassen 2005), and of visual images of women politicians with minority background in Danish newspapers (Elg 2002) have characterized the media as a discriminatory site.

One aspect of discrimination in the media deals with the border-drawing between the public and the private lives of politicians. 
Danish ethnic majority women politicians reported that media representation works as an example of discrimination and that the media work as the only site marked by a manifest level of gender inequality in their professional life (Moustgaard 2004a, 2004b). A study of Danish parliamentarians' self-representation on their websites concluded that the borders between public life and privacy are not undermined. However, privacy is presented in a controlled fashion and within certain limits. When a parliamentarian reveals aspects of his or her privacy, it represents a type of performance. Privacy is not rendered invisible, but is used as a way of creating personality and identity through the inclusion of narratives on childhood, spare time, and family relations. Seemingly, there are gendered differences in the way the parliamentarians perform privacy on their web sites (Hansen 2009). This is in opposition to Højgaard's (2001) study of Danish parliamentarians, who predominantly reject the significance of gender in their political life.

\section{A PERSPECTIVE OF INTERSECTIONALITY}

A perspective of intersectionality indicates that the focus of the analysis is broader than a gender perspective and that the relationship between social categories forms an open empirical question (Hancock 2007).

I approach intersectionality by drawing on the work of Phoenix to derive a conceptual language for recognizing that everybody is positioned simultaneously within social categories, such as class, ethnicity, gender, race, and sexuality. So even when focusing particularly on one social category, intersectionality reminds us that we cannot understand the category in isolation (Phoenix 2006). A perspective of intersectionality can reveal diversity among women and among men and illustrate how categories of difference and social divisions can be used for different purposes for different people, depending on their positioning.
Intersectionality is grounded in the thinking that studies of gender are always related to other social categories that work together to define a person's particular subject positions (e.g. Crenshaw 1994, Phoenix 2006, Yuval-Davis 2006). Therefore, a perspective of intersectionality offers the possibility of analysing the ways in which socio-cultural hierarchies interact and create inclusion and exclusion on the basis of discursive or institutional categories.

With Yuval-Davis, I argue that social divisions are about macro axes of social power, but also involve actual, concrete people. These divisions have organizational, intersubjective, experiential and representational forms. Regarding representation, the social divisions are expressed in images and symbols, texts and ideologies. As will become apparent below, discourses of naturalization tend to homogenize social categories and to treat all who belong to a particular social category as sharing equally the particular natural attributes of that category (Yuval-Davis 2006).

\section{RESEARCH ON MEDIA REPRESENTATION OF WOMEN POLITICIANS}

I will now present some relevant research based on North American, British, Canadian, Danish and Norwegian data. The most frequently cited international research on press coverage of women politicians only apply a perspective of intersectionality on media studies to a limited extent. In Danish research, two references are Elg (2002) and Andreassen $(2005,2006)$.

One key conclusion of international research is that female and male politicians are treated differently in the media and that women politicians are less visible and mentioned in significantly fewer stories than their male colleagues (Carroll and Schreiber 1997, Eide 2000, Norris 1997, Ross and Sreberny 2000). Even when women are visible, the media coverage tends to be rather narrowly focused in stereotypically 
feminine terms (Gidengil and Everitt 2003, Childs 2008). Professional women are domesticated in media representation as journalists insist on locating them in a feminine domain (Ross and Sreberny 2000, WahlJorgensen 2000). The media generally puts style over substance in relation to women politicians by using sex-specific narrative frames featuring descriptions of clothes, hair, demeanour, motherhood, and family.

A second conclusion is that working conditions in the media are different for female and male politicians. An American study of press coverage in the 103rd Congress investigated women politicians in relation to the quantity and quality of media representation (Carroll and Schreiber 1997). Newly elected women received more mentions by name in major papers than their male counterparts. For the most part, the women were portrayed as agents of change making a difference on issues of women's health, abortion, health care reform, and violence against women. On the other hand, the analysis illustrated that the media representation was based on genderbiased characteristics of the family-work life balance.

A project on media representation in the written press carried out by journalist Ulrikke Moustgaard (2004a, 2004b) was based on a gender perspective, focusing on Danish majority women politicians. The analysis considered difference-making categories such as age, gender, and sexuality but did not reflect on ethnicity or on the ways these categories intersected. Moustgaard identified some commonly employed stereotypes and concluded that the way the Danish media represent women politicians of majority origin is based on a type of sexualisation that emphasises the politicians' appearance and their private lives. At the time of the investigation, there were no women politicians with minority background in parliament.

\section{INTERSECTIONALITY AT WORK}

Minority women were first elected to the national parliament in 2007. Özlem Cekic of the Socialist People's Party was the first woman of minority background elected to the Danish parliament together with the Social Democrat Yildiz Akdogan. During the election campaign, the candidate Asmaa Abdol-Hamid from the most left-wing party The Red-Green Alliance received most attention in the media, but she was not elected. Previously, other women candidates with minority background have received a lot of media attention especially in relation to their approach to Islam (Elg 2002).

These historical points raise a question of how a woman politician from a minority background is represented in the Danish written press in terms of categories of social differences such as class, ethnicity, gender and religious beliefs. Rather than investigating how much media coverage the candidate and newly elected MP Özlem Cekic received in 2007, I am interested in the quality of the media representation and in what is rendered visible and invisible in the usage of social categories describing the election campaign of a minority woman politician. Three themes stand out in the media representation. ${ }^{4}$

\section{A TURKISH WOMAN FROM A WORKING-CLASS BACKGROUND}

Özlem Cekic presents herself in the media as a minority woman with a Turkish working class background. This self-representation is in contrast to the dominant media representation of her as one of two Muslim women elected to parliament for the first time at the 2007 election (Information 2.11.2007, JyllandsPosten 15.11.2007, Weekendavisen 23.11.2007) or as one of two women MPs with an immigrant background (Kristeligt Dagblad 9.11.2007, Nyhedsavisen 1.11.2007, 24timer 15.11. 2007). Whereas the media represent her as 
a woman politician with Muslim background, she constructs a different self-representation as a politician with an immigrant working class background.

First, her self-representation describes her class journey from a working class background to obtaining her degree as a nurse, to becoming active in her trade union and to being elected as a parliamentarian. She links her background with her political vision. "When someone like me comes from a low social class, you don't want to help the wealthy man from Hellerup [a wealthy Copenhagen suburb - CF] get a new Audi" (BT 11.11.2007). Her class journey has also had a price. She describes a type of alienation when explaining her childhood friends about her political struggles and victories while they talk about shopping in discount supermarkets (Information 2.11. 2007). Secondly, her ethnic minority background is downplayed in her self-representation. She points out that the fact that she is the first woman with minority background to be elected to the Danish parliament seems to be more important to journalists and others than it is for her. "I am both a woman and a Muslim, but first and foremost, I am a socialist" (24timer 15.11. 2007).

When people say: "It's great that an immigrant woman like you has gone so far", then I think: bullshit. The good side of this story is that I am trained as a nurse and come from an unskilled family. My parents are real guest workers. They left Turkey because they dreamt about having money to buy 40 sheep and a house in the village. My mum has been cleaning the schools in Copenhagen, and now I have come so far. That is fantastic, not that I am more sun-tanned than you are. But everyone else thinks that is exciting.

(Weekendavisen 23.11.2007, translation by the author)

\section{A MOTHER AND A POLITICIAN}

The fact that Özlem Cekic gave birth to her second child shortly before the parliamentary election is another key theme in the media representation of her and equally in her self-representation. The media construct her as a mother who is running for a parliamentary seat combining breastfeeding and baby care between debate arrangements and interaction with voters when she is in the streets rallying. Besides, her election campaign is represented as a collective family project headed by her husband, who has prolonged his paternity leave (Kristeligt Dagblad 26.10.2007). Seemingly, Özlem Cekic is successful in performing this aspect of her private life in the media employing the motherhood and familial activities as a way of constructing an identity (Hansen 2009). Hence the headlines "Mor blev valgt" (Mum got elected) (Ekstra Bladet 14.11.2007).

As we have seen previously, women politicians' bodies are often sexualized in media representations via the categories age, gender, and sexuality. In the case of Özlem Cekic the bodily representation takes a different form, focusing on gender and motherhood with a specific focus on her breastfeeding in between political rallies (BT 11.11.2007, Information 2.11.2007). However, the categories of gender and motherhood intersect with her religious beliefs in one type of media representation in the newspaper Information (2.11.2007) with the headline "Jeg gider ikke at tale om religion" (I don't feel like talking about religion).

Journalist: "I have often talked with Muslim women who have stressed that Islam gives women the right to earn their own money and to be politically active as long as it does not hurt their families. Do you live up to that at the moment?"

OC: “I don't really know, but I do not use the Koran or my religions belief to determine 
whether I am a good mother. I can read the Koran, but I rarely do. It is not that (book) which I consult when I am in doubt. In that sense, religion does not play any special role in my daily life. It does for some Muslims but not for me"

(Information 2.11.2007, translation by the author)

We saw above how Özlem Cekic's self-representation in the media downplayed the category ethnicity and emphasized class and political ideology as a socialist instead. Regarding the media representation, it is as if she cannot escape her religious belief even in relation to her motherhood practice.

\section{A SOCIALIST AND A MUSLIM WOMAN}

How do the Danish media represent a minority woman politician in terms of gender and religious beliefs when the politician is a Muslim? These two elements are clearly related in media representations of Özlem Cekic. During the election campaign, she is interviewed on issues related to religion and religious practices as a Muslim woman. In several interviews, Cekic points out that religion is a private matter (Kristeligt Dagblad 9.11.2007) and that being a Muslim is an 'extremely private identity' (Nyhedsavisen 1.11.2007). An identity she does not consider a political advantage (Information 2.11.2007). "I was asked to write a book chapter for a book on the Muhammad cartoon crisis, but honestly, I was much more concerned about waiting lists for patients in the psychiatric system" (Information 2.11. 2007, translation by the author).

The above can, in Yuval-Davis' terms, be interpreted as a discourse of resistance (Yuval-Davis 2006). Özlem Cekic refuses to accept the 'naturalizing narratives' on her religions beliefs as a Muslim. She refuses to be identified with all who belong to the special social category of Muslim women and refuses to share its particular attributes (Yuval-Davis 2006). She points out that it is a vital political point for her to separate politics and religion (JyllandsPosten 1.5.2007, 15.11.2007, Information 2.11. 2007). "I am of the opinion that religion and politics have to be separated. I am a nurse and I consult my medical catalogue more than the Koran. I fast and believe in God, but apart from that my religion is a private matter" (Kristeligt Dagblad 9.11. 2007, translation by the author).

In specific historical situations some social divisions are more important than others (Yuval-Davis 2006) and the fact that Özlem Cekic is a Muslim woman dominates media representations of her. This can be interpreted as a consequence of a contemporary Danish political-historical context in which ethnicity related to Islam is considered a barrier for a democratic approach to politics. Özlem Cekic points out that she does not run for parliament to prove that one can be a democrat and a Muslim, because a democrat is what she is. "The more I talk about religion, the less time there is to talk about politics" (Weekendavisen 23.11.2007).

\section{POWER IN THE MEDIA}

One way to analyse media power is by looking at the intersection of differencemaking categories in media representations and the social hierarchies they create. The way the categories or social divisions of class, ethnicity and gender are employed in the media representation of Özlem Cekic illustrates how the categories change significance, depending on the type of representation the media employ; their own or the politician's self-representation. These changes are especially clear in her self-representation or 'discourses of resistance' in which class divisions and her class journey play a more central role than her ethnic background and her religion. Özlem Cekic's emphasis on her religion as a private 
matter clearly distinguished from her political ideology is turned around by the media and employed as a key element in the construction of her as a 'Muslim woman politician'.

An analysis of Danish media narratives on rape and visible minorities from a perspective of intersectionality illustrates how the social categories gender and ethnicity/ race change positions and how their respective significances transform themselves depending on the context. This shifting significance illustrates the fluidity of the categories and their internal relationship. In some cases, the narratives are constructed around gender, in other cases around ethnicity and race (Andreassen 2006). In the case of Özlem Cekic, the categories are equally changing; there is a strong emphasis on her ethnicity and her religious beliefs. Such constructions often reflect hegemonic discourses of identity politics that render invisible experiences of the more marginal members of that specific social category and construct a homogenized 'right way' to be member. Categorical attributes are often used to construct inclusionary/exclusionary boundaries that differentiate between the self and other, determining what is normal and what is not (Yuval-Davis 2006).

Verloo points at central differences between the social categories such as gender, class, sexuality etc. arguing that “... a 'one fits all' approach to addressing multiple discrimination is based on an incorrect assumption of sameness or equivalence of these social categories connected to inequalities and of the mechanisms and processes that constitute them" (Verloo 2006: 211). Whereas gender is "... commonly seen as having two positions that are perceived as originating in nature, in biology" (Verloo 2006: 216), ethnicity represents a multiple range of positions. Verloo's point is that inequalities are not equivalent, that social categories are connected to inequalities in different ways and that power strug- gles between various inequalities will always be present.

\section{CONCLUDING REFLECTIONS}

In normative terms, the democratic role of the media has been understood as a forum for a society's collective dialogue with and about itself (Keane 1991). Media representation can be considered a democratic problem or challenge - for example when groups of men and women have unequal access to the media in a democracy - a 'democratic malaise' (Gidengil and Everitt 2003: 574) and when media representation is based on stereotypes. Tensions between publicness and privacy and between visibility and invisibility, identified in the media and the public sphere, are played out, often with dramatic effect, in the realm of discourses on politics and politicians (Fraser 1992, Sreberny and van Zoonen 2000).

By moving from a gender perspective to an intersectionality perspective on media representation, new aspects of this 'democratic malaise' become visible. The move involves the deconstruction of the category 'women', which allows more precise analysis of different groups of women politicians and their working conditions in the media. Højgaard's (2001) analysis of power, gender and gendered actors in the Danish parliament concludes that gender as a category produces order and meaning in the political field. It remains to be seen how Danish print and electronic media will construct media representation of minority women politicians beyond the election campaigns of 2007. It will take more studies from an intersectionality perspective to conclude in what ways the media primarily works as a site of discrimination and/or empowerment for these politicians.

A first conclusion illustrates that Özlem Cekic performs a high degree of agency and is successful in deconstructing key 'naturalizing narratives' in the media of her as a religious representative of minorities. She 
engages in 'discourses of resistance' in presenting herself as a left-wing politician with a background in the health sector (YuvalDavis 2006).

\section{Notes}

1. I would like to thank Ann Phoenix and two anonymous reviewers for their constructive and creative comments to this article. An earlier version was presented at the First European Conference on Politics and Gender (ECPG) at the European Consortium for Political Research (ECPR) Queen's University, Belfast, January 21-23 2009 in the panel 'Gendering the Local, the Public Sphere and the Nation'.

2. The representation of female parliamentarians in the Danish parliament - Folketinget - has risen from $16 \%$ women in 1975 to $30 \%$ in 1987 and to $38 \%$ in 2007 .

3. A note on the delimitation of the article: the empirical case is an explorative study and a first insight into analyses of media representation of minority women parliamentarians in the Danish press from a perspective of intersectionality. This also means that a number of analytical themes and illustrations of the newspaper articles are not included in the analysis. The idea is to carry out a more systematic study of the media coverage in Danish written media of MP Özlem Cekic in a longer time period after her 2007 election campaign.

4. The following analysis is based on articles from Danish newspapers identified via a search in the media database INFOMEDIA using the terms 'Özlem Cekic' and 'election campaign' in 2007. Most articles appeared in the second half of 2007.

\section{LITERATURE}

- Andreassen, Rikke (2005): The Mass Media's Construction of Gender, Race, Sexuality and $\mathrm{Na}$ tionality. An Analysis of the Danish News Media's Communication about Visible Minorities. PhD thesis. University of Toronto, Toronto.

- Andreassen, Rikke (2006): "Intersektionalitet i voldtægtsnarrativer”, in: Kvinder, Køn \& Forskning 2006/2-3, 93-104.

- Carroll, Susan J. and Schreiber, Ronnee (1997):

"Media Coverage of Women in the $103^{\text {rd }}$ Congress", in: Pippa Norris (ed.): Women, Media, and Politics. Oxford University Press, New York/Oxford.
- Childs, Sarah (2008): Women and British Party Politics. Descriptive, substantive and symbolic representation. Routledge, London.

. Crenshaw, Kimberlé Williams (1994): “Mapping the Margins: Intersectionality, Identity Politics, and Violence against Women of Color", in: Martha Fineman and Rixanne Mykitiuk (eds.): The Public Nature of Private Violence. The Discovery of Domestic Abuse. Routledge, London. - Eide, Elisabeth (ed.) (2000): Narrespeil. Kjønn, sex og medier. Høyskoleforlaget, Kristiansand.

. Elg, Camilla (2002): "Hellig krig om bare røve en introduktion til billedanalyse", in: Michael Hviid Jacobsen, Søren Kristiansen and Annick Prieur (eds): Liv, Fortalling, Tekst. Strejftog $i$ kvalitativ sociologi. Aalborg Universitetsforlag, Aalborg. - Fiig, Christina (2009a): "Women in Danish Politics: Challenges to the Notion of Gender Equality", in: Joyce Gelb and Marian Lief Palley (eds.): Women and Politics Around the World: A Comparative History and Survey. ABC-CLIO, Santa Barbara, CA.

. Fiig, Christina (2009b): “Køn og magt i dansk politik og centraladministration", in: Kirsti Niskanen and Anita Nyberg (eds.): Kön och makt $i$ Norden : Del 1 landsrapporter. Nordisk Ministerråd, København.

- Fraser, Nancy (1992): "Rethinkning the Public Sphere: A Contribution to the Critique of Actually Existing Democracy", in: Craig Calhoun (ed.): Habermas and the Public Sphere. MIT Press, Cambridge, MA.

- Gidengil, Elisabeth and Everitt, Joanna (2003):

"Conventional Coverage / Unconventional Politicians: Gender and Media Coverage of Canadian Leaders' Debates 1993, 1997, 2000", in: Canadian Journal of Political Science 36(3).

- Gomard, Kirsten and Krogstad, Anne (eds.) (2001): Instead of the Ideal Debate. Doing Politics and Doing Gender in Nordic Political Campaign Discourse. Aarhus University Press, Aarhus. - Hagemann, Gro and Krogstad, Anne (eds.) (1994): Høydeskrekk-kvinder og Offentlighed. Ad Notam, Gyldendal, Oslo.

- Hancock, Ange-Marie (2007): "When Multiplication Doesn't Equal Quick Addition: Examining Intersectionality as a Research Paradigm", in: Perspectives on Politics $5(1)$,.

- Hansen, Lene (2009): "Private mænd og offentlige kvinder. Køn som performance på danske politikeres personlige hjemmesider", in: Anne Jerslev and Christa Lykke Christensen (eds.): Hvor går gransen? Brudflader $i$ den moderne mediekultur. Tiderne skifter, Copenhagen.

- Højgaard, Lis (2001): "At komme til magten - 
magt, køn og kønnede aktører i det politiske felt", in: Dansk Sociologi 4.

- Jensen, Torben K. (2004): Folketingets mange funktioner. Aarhus University Press, Aarhus.

- Wahl-Jorgensen, Karin (2000): “Constructing Masculinities in U.S. Presidential Campaigns: The Case of 1992", in: Annabelle Sreberny and Lisbet van Zoonen (eds.): Gender, Politics and Communication. Hampton Press Inc., Cresskill, NJ.

- Keane, John (1991): The Media and Democracy. Polity Press, Cambridge.

- Moustgaard, Ulrikke (2004a): Håndtasken, heksen og de blåøjede blondiner. Danske, kvindelige politikere ifolge pressen - og dem selv. Roskilde University Press, Roskilde.

- Moustgaard, Ulrikke (2004b): The Handbag, The Witch and The Blue-eyed Blonds: Mass Media in (Re)Distribution of Power. www.medijuprojekts.lv - Norris, Pippa (ed.) (1997): Women, Media, and Politics. Oxford University Press, New York/Oxford.

- Phoenix, Ann (2006): "Interrogating Intersectionality: Productive ways of theorising multiple positioning”, in: Kvinder, Køn \& Forskning 2006/2-3.

- Ross, Karen and Sreberny, Annabelle (2000): "Women in the House: Media Representation of British Politicians", in: Annabelle Sreberny and Lisbet van Zoonen (eds.): Gender, Politics and Communication. Hampton Press Inc., Cresskill, NJ.

- Ross, Karen (2003): Women Politicians and Malestream Media. CAWP Occasional Paper, Belfast.

- Sreberny, Annabelle and van Zoonen, Lisbet (2000): Gender, Politics and Communication: An Introduction", pp.11-20 in: Annabelle Sreberny and Lisbet van Zoonen (ed.). Gender, Politics and Communication. Hampton Press Inc., Cresskill, NJ.

- Verloo, Mieke (2006): "Multiple Inequalities, Intersectionality and the European Union", in: European Journal of Women's Studies 13(3).

- Yuval-Davis, Nira (2006): "Intersectionality and Feminist Politics", in: European Journal of Women's Studies 13(3).

\section{QUOTED NEWSPAPER ARTICLES}

- Bendix Olsen, Maria (2007): "Det bliver nogle lange dage i institutionen", Kristelig Dagblad, d. 26. oktober: 3 .

· Damsgård Andersen, Puk (2007): "Villy Søvndals liste Femme Fatale", Jyllands-Posten, d. 16. november: 2 .
. Ejlertsen, Martin (2007): "Nye stemmer i Tinget", Kristelig Dagblad, d. 9. november: 3.

- Ekstra Bladet (2007): "Mor blev valgt", Reportage, d 14. november: 5 .

- Gunge, Ulla (2007): "Hun vil gøre Khader kunsten efter", Nyhedsavisen, d. 1. november: 20.

- Jacobsen Turner, David (2007): "Mønsterbryder: Først og fremmest socialist", Weekendavisen, d. 23. november: 2 .

· Jyllands-Posten (2007): "De udsattes stemme", 1.sektion, den 15. november: 5 .

. Leth, Anne Louise (2007): "Den grønne og den garvede". BT, d. 11. november 2007:6.

- Mygind, Johanne (2007): "Jeg gider ikke at tale om religion". Dagbladet Information, d. 2. november: 36-37.

- Møbjerg, Lene (2007): "Religiøse socialister er klar til valgkamp", Jyllands-Posten, d. 1. maj: 5. . Thomsen, Signe (2007): "Den første indvandrerkvinde er i Folketinget", 24timer Aarbus, d. 15. november: 4 .

\section{SUMMARY}

Media Representations of Women Politicians from a Gender to an Intersectionality Perspective.

This article investigates media representation from a perspective of intersectionality defined as one that deconstructs the category 'woman' by looking at different social divisions such as class, ethnicity, gender, race and sexuality. An intersectionality perspective is constructive in broadening the debate on the media as a powerful political site for different groups of men and women politicians. The analytical point of the article is that a perspective of intersectionality deepens the understanding of the ways that the media organize power through stereotypical representation and homogenization of social categories.

Christina Fiig, Associate Professor, PhD

Department of History, International and Social Studies

Aalborg University, Denmark 